Article

\title{
Water Price Effects on Consumption and Territorial Imbalances in Spain in the Context of the Water Framework Directive
}

\author{
Marcos García-López *(i) and Borja Montano (D) \\ University Institute of Water and Environmental Sciences, University of Alicante, \\ 03690 San Vicente del Raspeig, Spain; borja.montano@ua.es \\ * Correspondence: marcos.garcialopez@ua.es
}

Received: 21 April 2020; Accepted: 3 June 2020; Published: 4 June 2020

check for updates

\begin{abstract}
This research examines the water tariff applied to Spanish households with the aim of determining the adequacy of the river-basin approach established by the water framework directive (WFD). The analysis pays particular attention to Spain's interregional differences in water prices, as well as determining the most influential factors in household water consumption. The results achieved through minimum ordinary squares and 2-stage least squares show the great influence of relevant factors such as the composition of the household, as the most populated households are penalized by the structure of the rate. In addition, there is evidence of inefficiency of the approach derived from the existence of regional differences, since the prices are higher in those regions where resources are reduced, a fact related to the higher cost of service. Thus, taking into account the excessive attention to the cost of the service, the results obtained allow to propose a change in the rate with the aim of balancing prices between regions taking into account factors such as the structure of the household or income.
\end{abstract}

Keywords: water resources; water prices; water policy; cost recovery of water services; price imbalances between regions

\section{Introduction}

In Spain, the geographical and temporary distribution of water resources is a problem according to its imbalances between demand and supply [1]. In addition, the incidence of droughts is unstable and annual rainfall has declined despite the increase in torrential rains [2]. An example of this is the water exploitation index plus (WEI+) calculated by the European Environment Agency for each European river basin. This index, shown in Table A1, is calculated as the proportion of water resources consumed on renewables for a particular region and period. Thus, water stress values for the Spanish basins vary considerably by season. On one hand, in the autumn-winter months the pressure on water resources is lower than during the spring-summer months. This seasonal nature of the water supply requires specific measures depending on the time of year to solve the problem [3], which is supported by differences in terms of the consumption pattern [4]. On the other hand, regional differences are observed depending on certain characteristics such as available resources, climatology, population or economic activities that are carried out, as this has a direct effect on water consumption [5]. These characteristics are also related to the conditions in which the water service is provided, which affects the quality of this service through the presence of economies of scale, the availability of resources or the quality of the water available, among others [6]. Therefore, even in regions with similar characteristics, the influence of these factors may be different so the regulatory and 
pricing measures must be adapted in each situation [7,8]. In addition, the excessive consumption of water by Spanish households is higher than the 100-liters per person, per day that World Health Organization (WHO) considers appropriate [9]. Thus, regional and seasonal imbalances and excessive consumption by citizens are observed justifying the search for alternatives to improvement. However, these regional differences could be due in part to the characteristics of each region, which influence the management of water resources, and it is therefore necessary to study them in order to induce equity in the system without harming certain regions. Regarding consumption, the WHO recommendation is a reference value for the water we need, so it is used as a reference for responsible consumption since, unfortunately, the information needed to measure consumption efficiency in economic or social terms is not available.

With the objective to address these problems, water policy aims to balance economic growth and social well-being with the proliferation of the natural environment [10]. To this end, there are several tools, including the water pricing policy which, in addition to present several additional effects, allows to combat the problems mentioned above [11]. In general, appropriate water pricing enables the pursuit of economic efficiency, financial sustainability, responsible resource use, social concerns or improved governance [12]. In particular, social issues have an important relation with tariff equity and the affordability of water services, which can be addressed through appropriate tariff design [12]. Currently, the Spanish water tariff is composed of a variable part that penalizes high consumption and a fixed part that guarantees a certain level of income. However, the tariff structure should not be taken for granted and measures as altering the balance between the fixed and variable parts of the invoice or implementing measures about household composition would improve the effectiveness of the tariff without penalizing the vulnerable households [13]. There are other measures that would modify the performance of the tariff to a greater extent, such as the implementation of a water market [14] or pricing based on scarcity [15], however, simple tariffs are more effective than complex ones [12]. Thus, the payment for environmental services can provide an efficient way to address the growing interconnections, which are increasingly global [16]. Currently, cost recovery method is addressed at the river basin level as established by the water framework directive (WFD), as decisions must be made as close as possible to the locations where water is used or affected [17]. It should be explained that cost recovery is measured as the proportion of revenues to financial costs (financial costs recovery) or totals (total costs recovery). However, management is fragmented, as water pricing is competency of the local government, which sets a price commensurate with the cost of supply and its budgetary situation, while the tax to finance wastewater treatment is a regional responsibility. Therefore, in Spain a contradiction between the system established by the WFD and the applied to obtain revenues is present. As a result, problems of price equity between regions and even imbalances in terms of cost recovery between the different river basins may occur [18], but, as mentioned above, the characteristics of each region must be considered, as balancing prices between regions that require different management of water resources would be unfair.

In this sense, the WFD establishes the complete costs recovery with the aim of achieving the sustainability of water services. These costs include two types, totals and sustainability, referring the latter to those necessary for the activity to continue. Covering these costs is essential in the long term, however, in the short term other aspects must be taken into account [11], in particular, to properly assess the consequences of price change in order to induce efficiency, that is, the price set must be socially acceptable [19]. It should be noted, however, that low prices are a disincentive for innovation by users through encouraging inefficient consumption [20]. Therefore, policy design must be careful and precise with the aim of developing measures as efficiently as possible [21].

In order to establish an appropriate water pricing policy capable of financing costs, it is necessary to know the influence it has on consumers. This aspect of politics has been very much addressed in the literature because of its importance and difficulty, highlighting two fundamental issues when analyzing the price of water. First, the existence of increasing block tariffs, which presence implies a higher price 
per cubic meter as consumption increases. Thus, simultaneous determination of consumption and price may lead to a bias that directly affects the results achieved [22,23]. Second, price perception is a matter of interest because, while there is consensus on the existence of a temporary delay, at what price users respond to is a controversial issue. In this sense, the consumer could react to the marginal price, at which consumer would tend to react in the case of perfect information [22] or to the average price, which is easier to observe due to lack of information of consumption due, in part, to the existence of the temporary delay $[5,24]$. Therefore, this fact presents, for the researcher, an additional problem in determining the reaction to price of the user of the service [5].

Likewise, one aspect that must be assessed in terms of consumer reaction is the possibility that urban demand is relatively inelastic with respect to price when it is too low [25]. In this situation, the consumer would not react to price because the low proportion it would have on their budgets limits the price perception [26]. However, not all consumers react in the same way to a price increase, with those with lower incomes or tighter family budgets reacting more intensely to the price in search of savings [27]. In other words, both price and income are determinants of consumption, so a distinction between price-induced and income-induced variation in consumption should be made. Despite this variation in consumption incited by price, there is a necessary consumption for each household that is not susceptible to reduction and represents a significant part of total $[28,29]$. This aspect should be taken into account in the design of pricing policy with the aim of not harming low-income households, as well as ensuring the well-being of citizens through a more efficient resource management [30] and the possibility of reinvesting additional income in low-income-favoring measures [31]. Therefore, price measures must be accompanied by knowledge about the consumer, as well as regulatory measures, in order to achieve the desired effect [32].

The main objective of this study is to determine the reaction of consumers to price variations in Spain in order to evaluate and reform the price policy in a territory that suffers from shortages, lack of cost recovery and high consumption. This study uses a database containing price and consumption of residential water for a representative sample for the whole of Spain, which differs from the usual studies focused on specific regions $[13,33]$ or groups of cities [34]. In this sense, this analysis allows for the detection of differences between regions in terms of water rates, which makes it possible to observe the penalty of residing in a specific region of Spain. For this reason, the analysis also incorporates a price comparison by region including relevant aspects such as consumption or income. In this regard, the analysis seeks to determine whether the current cost recovery system per river basin is efficient or could be improved. Since the river basin approach is determined by the water framework directive, the changes are conditioned by this approach even though the current system contradicts the scale at which revenue is collected and there is a lack of financing. To this end, this introduction is followed by an explanation of the data used, as well as the methodology applied. After this, the results section will show the estimates and their meaning, so that the discussion section can comment on their implications. Finally, the conclusions will concisely show the contribution of the research.

\section{Materials and Methods}

In order to analyze the current situation of price imbalance at regional level, data about the budgetary situation of households is utilized. This allow to analyze water pricing at household scale, but distinguishing by region, so that a high level of disaggregation is available while territorial comparisons can be established. For this purpose, descriptive evidence and econometric regression techniques are used to analyze the determinants of water consumption and tariff. 


\subsection{Materials}

Regarding the data, the Family Budget Survey prepared by the National Statistical Institute of Spain (INE by its Spanish acronym) is utilized. This survey includes data from 2006 to 2018, nevertheless, a methodological change affecting data from 2016 and the new sampling in each edition prevents the data from being treated as time series or panel data. Therefore, the data are treated as cross section data including the editions of 2016, 2017 and 2018, so that year variables are included to control differences per year. This survey contains the total expenses that families face annually as well as certain basic household characteristics that improve the analysis. Consequently, this survey is not specific about water consumption, so it does not include aspects related to climate, tourism or delayed price perception.

The main study variables are the price and consumption of water since the aim is to analyze their determinants for the Spanish case with econometric techniques. The other variables included in the analysis are shown in Table A2 of the Appendix A, as it is considered that they can be related to price and consumption. Income, as well as other characteristics of the household such as its composition, can influence the consumption pattern and, by extension, the prices to pay [35,36]. In particular, it is expected to find that higher income or number of members are associated with higher water consumption per household. Regional characteristics are relevant when explaining consumption and price, so the available data on municipality size, population density and occupied capacity of the reservoirs are included in the analysis $[5,7,8,36]$. It is expected that the larger the municipality or population density, the lower the consumption per household, while greater availability of water resources would be related to higher consumption. In this sense, the main variables of interest are the consumption of water per household (measured in cubic meters) and the unit price (measured as total invoice divided between total consumption of every household, that is, Euros per cubic meters), in both cases of an annual nature. That is, there are two types of estimations depending on whether the variable to explain is consumption or price, which are shown in Tables 1 and 2, respectively. However, although consumption represents the total of the household, the price only includes the standard tariff because there is a significant lack of information about the payment for wastewater treatment. In addition, the price included in the analysis is the unit price, as the marginal price cannot be obtained with the available data. The other variables introduced correspond to the characteristics of the household surveyed, population density, municipality size, region and average capacity used in the last 10 years of the region's reservoirs. The reservoir variable comes from the website embalses.net and is an estimate from a figure due to the non-response of the website. Household characteristics are introduced through continuous variables, such as the number of household members and the annual household income measured in euros, while the rest are inserted as dichotomous variables that use as reference the category with the lowest value. In this sense, population density variables are in reference to low density, municipality size variables in reference to population less than 10,000 inhabitants, region variables in reference to Aragon, which presents the lowest consumption and reservoir variables leave out those with an occupied capacity of less than $40 \%$.

In addition, in order to eliminate responses away from reality, outliers based on various criteria were removed. In terms of consumption, cases where consumption exceeds 1500 cubic meters per person per year or shows a logarithm of water consumption below-1 was eliminated. As regards the price, observations with a unit price of more than six Euros, a total invoice of more than 1000 Euros per person per year or a weight of the invoice on the household budget of more than $25 \%$ were eliminated. Finally, cases with an income of more than 15,000 Euros per month were also deleted. The final sample remains in 62,195 observations after the elimination of 138 households of 62,333 . 
Table 1. Models with consumption per household as the dependent variable.

\begin{tabular}{|c|c|c|}
\hline Dependent Variable: Consumption per Household & Ordinary Least Square & 2-Stage Least Square \\
\hline Residing in a city between 10,000 and 20,000 inhabitants & $\begin{array}{l}-0.017 \\
(0.009)\end{array}$ & $\begin{array}{c}-0.087 \\
(0.023)^{* * *}\end{array}$ \\
\hline Residing in a city between 20,000 and 50,000 inhabitants & $\begin{array}{l}-0.007 \\
(0.014)\end{array}$ & $\begin{array}{c}-0.267 \\
(0.064)^{* * *}\end{array}$ \\
\hline Residing in a city between 50,000 and 100,000 inhabitants & $\begin{array}{c}-0.045 \\
(0.016) * * *\end{array}$ & $\begin{array}{c}-0.394 \\
(0.084)^{* * *}\end{array}$ \\
\hline Residing in a city with more than 100,000 inhabitants & $\begin{array}{c}-0.170 \\
(0.016) * * *\end{array}$ & $\begin{array}{c}-0.707 \\
(0.126)^{* * *}\end{array}$ \\
\hline Residing in a medium density area & $\begin{array}{c}0.096 \\
(0.010)^{* * *}\end{array}$ & $\begin{array}{c}0.148 \\
(0.020)^{* * *}\end{array}$ \\
\hline Residing in a high-density area & $\begin{array}{c}0.059 \\
(0.015)^{* * *}\end{array}$ & $\begin{array}{l}-0.004 \\
(0.028)\end{array}$ \\
\hline Number of members in the household & $\begin{array}{c}0.110 \\
(0.002) * * *\end{array}$ & $\begin{array}{c}0.107 \\
(0.004)^{* * *}\end{array}$ \\
\hline Annual income of the household $(€)$ & $\begin{array}{c}0.002 \\
(0.000)^{* * *}\end{array}$ & $\begin{array}{c}0.006 \\
(0.000)^{* * *}\end{array}$ \\
\hline Unit price of water consumed $\left(€ / \mathrm{m}^{3}\right)$ & $\begin{array}{c}-0.814 \\
(0.013)^{* * *}\end{array}$ & $\begin{array}{c}-2.947 \\
(0.501)^{* * *}\end{array}$ \\
\hline Unit price * Income & $\begin{array}{c}0.000 \\
(0.000)^{* * *}\end{array}$ & $\begin{array}{l}- \\
-\end{array}$ \\
\hline Observation of the year $2017^{1}$ & $\begin{array}{c}0.024 \\
(0.007)^{* * *}\end{array}$ & $\begin{array}{l}-0.004 \\
(0.013)\end{array}$ \\
\hline Observation of the year $2018^{1}$ & $\begin{array}{l}-0.006 \\
(0.007)\end{array}$ & $\begin{array}{l}-0.003 \\
(0.012)\end{array}$ \\
\hline Constant & $\begin{array}{c}4.501 \\
(0.018)^{* * *}\end{array}$ & $\begin{array}{c}5.321 \\
(0.192)^{* * *}\end{array}$ \\
\hline $\begin{array}{c}\text { Adjusted } R^{2} \\
N\end{array}$ & $\begin{array}{c}0.26 \\
62,195\end{array}$ & $\begin{array}{c}- \\
62,195\end{array}$ \\
\hline
\end{tabular}

Table 2. Models with price per household as the dependent variable.

\begin{tabular}{|c|c|c|c|}
\hline Dependent Variable: Unit Price & Initial Estimation & Estimation with Regions & Estimation with Reservoirs \\
\hline $\begin{array}{l}\text { Residing in a city between } 10,000 \text { and } \\
20,000 \text { inhabitants }\end{array}$ & $\begin{array}{c}-0.080 \\
(0.008)^{* * *}\end{array}$ & $\begin{array}{c}-0.046 \\
(0.008)^{* * *}\end{array}$ & $\begin{array}{c}-0.083 \\
(0.008)^{* * *}\end{array}$ \\
\hline $\begin{array}{l}\text { Residing in a city between } 20,000 \text { and } \\
50,000 \text { inhabitants }\end{array}$ & $\begin{array}{c}-0.174 \\
(0.011)^{* * *}\end{array}$ & $\begin{array}{l}-0.157 \\
(0.011)^{* * *}\end{array}$ & $\begin{array}{c}-0.218 \\
(0.012) * * *\end{array}$ \\
\hline $\begin{array}{l}\text { Residing in a city between } 50,000 \text { and } \\
100,000 \text { inhabitants }\end{array}$ & $\begin{array}{c}-0.225 \\
(0.012)^{* * *}\end{array}$ & $\begin{array}{c}-0.154 \\
(0.012)^{* * *}\end{array}$ & $\begin{array}{c}-0.247 \\
(0.013)^{* * *}\end{array}$ \\
\hline $\begin{array}{l}\text { Residing in a city with more than } 100,000 \\
\text { inhabitants }\end{array}$ & $\begin{array}{c}-0.308 \\
(0.012)^{* * *}\end{array}$ & $\begin{array}{c}-0.230 \\
(0.012)^{* * *}\end{array}$ & $\begin{array}{l}-0.322 \\
(0.013)^{* * *}\end{array}$ \\
\hline Residing in a medium density area & $\begin{array}{c}0.045 \\
(0.007)^{* * *}\end{array}$ & $\begin{array}{c}-0.012 \\
(0.007) *\end{array}$ & $\begin{array}{c}0.018 \\
(0.007) * *\end{array}$ \\
\hline Residing in a high-density area & $\begin{array}{l}-0.010 \\
(0.011)\end{array}$ & $\begin{array}{l}-0.037 \\
(0.011)^{* * *}\end{array}$ & $\begin{array}{c}-0.052 \\
(0.012)^{* * *}\end{array}$ \\
\hline Number of members in the household & $\begin{array}{c}0.023 \\
(0.002)^{* * *}\end{array}$ & $\begin{array}{c}0.024 \\
(0.002)^{* * *}\end{array}$ & $\begin{array}{c}0.027 \\
(0.002)^{* * *}\end{array}$ \\
\hline Annual income of the household $(€)$ & $\begin{array}{c}0.000 \\
(0.000)\end{array}$ & $\begin{array}{l}-0.000 \\
(0.000)\end{array}$ & $\begin{array}{c}-0.001 \\
(0.000) * *\end{array}$ \\
\hline
\end{tabular}


Table 2. Cont.

\begin{tabular}{|c|c|c|c|}
\hline Dependent Variable: Unit Price & Initial Estimation & Estimation with Regions & Estimation with Reservoirs \\
\hline Water consumption per household $\left(\mathrm{m}^{3}\right)$ & $\begin{array}{c}-0.002 \\
(0.000)^{* * *}\end{array}$ & $\begin{array}{c}-0.002 \\
(0.000)^{* * *}\end{array}$ & $\begin{array}{c}-0.002 \\
(0.000)^{* * *}\end{array}$ \\
\hline Consumption*Income & $\begin{array}{c}0.000 \\
(0.000)^{* * *}\end{array}$ & $\begin{array}{c}0.000 \\
(0.000)^{* * *}\end{array}$ & $\begin{array}{c}0.000 \\
(0.000) * * *\end{array}$ \\
\hline Observation of the year $2017^{1}$ & $\begin{array}{c}-0.015 \\
(0.005)^{* * *}\end{array}$ & $\begin{array}{c}-0.014 \\
(0.005)^{* * *}\end{array}$ & $\begin{array}{c}-0.017 \\
(0.005)^{* * *}\end{array}$ \\
\hline Observation of the year $2018^{1}$ & $\begin{array}{c}0.036 \\
(0.006)^{* * *}\end{array}$ & $\begin{array}{c}0.037 \\
(0.005)^{* * *}\end{array}$ & $\begin{array}{c}0.033 \\
(0.006)^{* * *}\end{array}$ \\
\hline $\begin{array}{l}\text { Residing in an area where reservoirs have an } \\
\text { occupied capacity between } 40 \% \text { and } 55 \%\end{array}$ & $\begin{array}{ll}- \\
-\end{array}$ & $\begin{array}{l}- \\
-\end{array}$ & $\begin{array}{c}0.046 \\
(0.009)^{* * *}\end{array}$ \\
\hline $\begin{array}{l}\text { Residing in an area where reservoirs have an } \\
\text { occupied capacity between } 55 \% \text { and } 70 \%\end{array}$ & $\begin{array}{l}- \\
-\end{array}$ & $\begin{array}{ll}- \\
-\end{array}$ & $\begin{array}{c}-0.155 \\
(0.008)^{* * *}\end{array}$ \\
\hline $\begin{array}{l}\text { Residing in an area where reservoirs have an } \\
\text { occupied capacity of more than } 70 \%\end{array}$ & - & - & $\begin{array}{c}0.031 \\
(0.008)^{* * *}\end{array}$ \\
\hline Andalusia & $\begin{array}{l}- \\
-\end{array}$ & $\begin{array}{c}0.349 \\
(0.010)^{* * *}\end{array}$ & $\begin{array}{l}- \\
-\end{array}$ \\
\hline Asturias & $\begin{array}{l}- \\
-\end{array}$ & $\begin{array}{c}0.211 \\
(0.012)^{* * *}\end{array}$ & $\begin{array}{l}- \\
-\end{array}$ \\
\hline Balearic Islands & $\begin{array}{l}- \\
-\end{array}$ & $\begin{array}{c}0.524 \\
(0.016)^{* * *}\end{array}$ & $\begin{array}{l}- \\
-\end{array}$ \\
\hline Canary Islands & $\begin{array}{l}- \\
-\end{array}$ & $\begin{array}{c}0.457 \\
(0.012)^{* * *}\end{array}$ & $\begin{array}{l}- \\
-\end{array}$ \\
\hline Cantabria & $\begin{array}{l}- \\
-\end{array}$ & $\begin{array}{c}0.164 \\
(0.011)^{* * *}\end{array}$ & $\begin{array}{l}- \\
-\end{array}$ \\
\hline Castilla and León & $\begin{array}{l}- \\
-\end{array}$ & $\begin{array}{c}0.079 \\
(0.012)^{* * *}\end{array}$ & $\begin{array}{l}- \\
-\end{array}$ \\
\hline Castilla-La Mancha & - & $\begin{array}{c}0.197 \\
(0.012)^{* * *}\end{array}$ & $\begin{array}{l}- \\
-\end{array}$ \\
\hline Catalonia & $\begin{array}{l}- \\
-\end{array}$ & $\begin{array}{c}0.620 \\
(0.011)^{* * *}\end{array}$ & $\begin{array}{l}- \\
-\end{array}$ \\
\hline Valencia & - & $\begin{array}{c}0.550 \\
(0.011)^{* * *}\end{array}$ & $\begin{array}{l}- \\
-\end{array}$ \\
\hline Extremadura & $\begin{array}{l}- \\
-\end{array}$ & $\begin{array}{c}0.255 \\
(0.011)^{* * *}\end{array}$ & - \\
\hline Galicia & $\begin{array}{l}- \\
-\end{array}$ & $\begin{array}{c}0.148 \\
(0.011)^{* * *}\end{array}$ & $\begin{array}{l}- \\
-\end{array}$ \\
\hline Madrid & $\begin{array}{l}- \\
-\end{array}$ & $\begin{array}{c}0.559 \\
(0.011)^{* * *}\end{array}$ & $\begin{array}{l}- \\
-\end{array}$ \\
\hline Murcia & - & $\begin{array}{c}0.423 \\
(0.011)^{* * *}\end{array}$ & $\begin{array}{l}- \\
-\end{array}$ \\
\hline Navarra & - & $\begin{array}{c}0.255 \\
(0.012)^{* * *}\end{array}$ & $\begin{array}{l}- \\
-\end{array}$ \\
\hline Basque Country & $\begin{array}{l}- \\
-\end{array}$ & $\begin{array}{c}0.066 \\
(0.009)^{* * *}\end{array}$ & $\begin{array}{l}- \\
-\end{array}$ \\
\hline La Rioja & $\begin{array}{l}- \\
-\end{array}$ & $\begin{array}{c}0.101 \\
(0.013)^{* * *}\end{array}$ & $\begin{array}{l}- \\
-\end{array}$ \\
\hline Ceuta & $\begin{array}{l}- \\
- \\
\end{array}$ & $\begin{array}{c}0.275 \\
(0.020)^{* * *} \\
\end{array}$ & $\begin{array}{l}- \\
- \\
\end{array}$ \\
\hline Melilla & - & $\begin{array}{c}-0.247 \\
(0.028)^{* * *}\end{array}$ & - \\
\hline Constant & $\begin{array}{c}1.736 \\
(0.014)^{* * *}\end{array}$ & $\begin{array}{c}1.379 \\
(0.015)^{* * *}\end{array}$ & $\begin{array}{c}1.823 \\
(0.016)^{* * *}\end{array}$ \\
\hline $\begin{array}{c}\text { Adjusted } R^{2} \\
N\end{array}$ & $\begin{array}{c}0.21 \\
62,195\end{array}$ & $\begin{array}{c}0.35 \\
62,195\end{array}$ & $\begin{array}{c}0.24 \\
56,658\end{array}$ \\
\hline
\end{tabular}

${ }^{*} p<0.1 ;{ }^{* *} p<0.05 ;{ }^{* * *} p<0.01 ;{ }^{1}$ year variables are introduced in order to control the differences due to changes between years. 


\subsection{Methods}

First, the results show descriptive evidence that are useful to contextualize the situation, after which econometric techniques applicable to cross section data are used with the aim of analyzing the determinants of water consumption and price related to Spanish households. In particular, ordinary least squares and 2-stage least squares are the analysis techniques, which are the techniques commonly used, especially when the data allow for addressing simultaneity bias [36]. Ordinary least squares allows to know the influence of a series of factors on the variable to predict, while 2-stage least squares allows to correct the simultaneity between, in this case, consumption and price. The latter is possible thanks to an instrument variable that replace the predictor determined together with the variable to explain. This requires the availability of additional predictors that allow the estimation of the problematic variable without falling into new problems of simultaneity. In this case, the instrument consists of a price estimate that replaces the original value and does not suffer from simultaneity with consumption. However, given the limited information available on household and regional characteristics, the instrument variable used in the 2-stage least squares model may not be robust due to lack of capacity to explain price without using consumption. In this sense, the variables included in the model apart from consumption and price are used as instruments but replacing the variable household members by the different types of household. ordinary least squares are utilized on more than once in order to study different aspects while 2-stage least squares seeks to face the simultaneity bias in the consumption model. Although 2-stage least squares is commonly used to correct this type of bias, there are cases where the use ordinary least squares does not show a particular effect on the price elasticity obtained compared with other techniques [37]. The equations to be estimated using these techniques are:

$$
\begin{aligned}
& C_{h}=X_{h} \beta+\varepsilon_{h} \\
& P_{h}=X_{h} \beta+\varepsilon_{h}
\end{aligned}
$$

where $C$ represents water consumption; $P$ the price paid for the water supply; $X$ is a vector of individual explanatory variables plus a constant term; $\beta$ is a vector of parameters and $\varepsilon$ is a random error term. The sub-index $h$ refer to the unit of analysis used, the households.

In this regard, five estimates are presented depending on the aspect analyzed. Equation (1) corresponds to the consumption model to be estimated through ordinary least squares and 2-stage least squares, so that differences between both estimations can be observed. In addition, when estimating Equation (1), consumption and price are introduced in logarithmic scale with the aim of obtaining the price coefficient in terms of demand elasticity. Thus, the coefficient obtained will show the percentage change in consumption in response to the percentage change in the unit price. On the other hand, Equation (2) corresponds to the pricing model, which is estimated 3 times. First, the basic model is estimated from household data, population density and municipality size. Second, the regional variables are added to the model in order to analyze the influence of residing in a particular location. Finally, a third estimate adding reservoir occupied capacity variables to the basic model seeks to provide evidence about the influence of resource scarcity on prices. However, this estimate eliminates the Canary Islands, the Balearic Islands, Ceuta and Melilla due to the unavailability of information about the condition of their reservoirs.

\section{Variance Inflation Factor}

Given the variables included in the analysis, there is a possibility of multicollinearity problems between predictors, reason why a rvariance inflation factor (VIF) test is performed. This technique allows to calculate the amount of variance of each variable due to the multicollinearity present in the estimation. Specifically, this test is performed by regressing each predictor in the model according to every other predictor included, allowing to analyze their correlation. Thus, Tables A3 and A4 of the Appendix A contain 
the results, in which it can be observed that the values of the variables are less than 10 (the usual limit), although the interaction of price and income is close to this limit probably due to its relationship with price and income. In addition, the regional variables do not show signs of correlation problems either. However, the lack of availability of spatial information limits the ability to analyze the importance of proximity between observations.

\section{Results}

The results achieved after analyzing the current situation in terms of consumption, prices and regional imbalances are discussed below. On one hand, descriptive evidence is presented in order to contextualize and justify the analysis and, on the other hand, the results referring to the econometric estimates of the Equations (1) and (2) seek to analyze the determining factors of consumption and price.

\subsection{Descriptive Evidence}

First, Table A2 contains the descriptive statistics of the set of variables introduced in the analysis including the mean and standard deviation of each of them. Thus, the regional variables, size of municipality and density show that a relevant proportion of the sample is located in small or very large cities and that approximately half of the sample belongs to areas with a high population density. In terms of regional distribution, a greater presence of households can be observed in more populated areas of the country. Thus, the inclusion of regional variables in the analysis is necessary when studying prices, which reveal important regional differences in terms of household characteristics. However, despite these differences, the water invoice represents a relatively low proportion of the budget of Spanish households. On the other hand, the differences between regions in terms of price and consumption are evident, so that the characteristics of each location must maintain a significant influence in the determination of the tariff and consumption pattern. In addition, the distribution of income among regions should be considered, so varies significantly and can condition the incidence of the tariff on households. These factors may be related to aspects such as the economic or political situation of each region, as well as its availability of resources or the cost of the service, among others. Nevertheless, a high variability is observed in all cases, thus showing important differences between Spanish households.

\subsection{Empirical Evidence}

Tables 1 and 2 provide the results regarding consumption and price models, respectively, after estimating Equations (1) and (2). In this sense, Table 2 seeks to determine the consumption pattern per household by estimating the Equation (1). The results evince a high influence of price in both models, 0.814 and -2.947 , respectively, highlighting the case of 2-stage least squares probably due to insufficient information about the determinants of the tariff. The difference is significant because with a price increase of $10 \%$, in the first case consumption would be reduced by $8.14 \%$ while in the second case it would be $29.47 \%$, which is difficult to achieve in practice. In any case, the estimates demonstrate a significant and negative effect of price on the consumption pattern of households. Regarding the income, a positive effect can be observed, since higher income leads to greater consumption, as well as a statistically significant effect of its interaction with price, thus showing differences in the reaction to the price according to income. In this case, this interaction could indicate that price influences positively on consumption as income grows, so the reaction to price depends on income and must be considered in the design of the water tariff. In addition, the number of household members is significant and positive, as would be expected. The population density, while significant, does not show a clear pattern, but it seems to indicate that there is less consumption per household in places where the population density is lower. However, the size of the municipality shows the opposite relationship, as the size of the municipality 
grows, consumption per household decreases. This could be related to demographic or socioeconomic differences between large and small cities, for example household composition or income. Unfortunately, the Adjusted $\mathrm{R}^{2}$ is relatively low, so that the explanatory capacity is limited and evinces the importance of factors that cannot be included in the analysis.

Table 2 provides the results referring to Equation (2), where unit price is taken as the dependent variable. In this case, consumption shows a negative and statistically significant relationship with price. Thus, as consumption increases, the unit price decreases due to the importance of the weight of the fixed part of the invoice, reducing the progressiveness of the tariff despite the presence of increasing blocks. Income, on the other hand, is only statistically significant in the model that considers the reservoirs, so there is evidence about the non-valuation of income in the elaboration of the tariff despite being a determinant of the consumption pattern, which is confirmed by the weight on the invoice shown in Table A5. In the case of not considering the economic situation of households, the tariff has an unequal impact among households, as can be seen from the high variability of the weight variable. Therefore, an analysis of the situation between price and household income is essential when determining the feasibility of a tariff increase, as it must not be forgotten that this is a basic service and must be affordable. On the other hand, a greater number of members per household is related to higher unit prices even when consumption per person is comparable to households with fewer members. This is due to the current structure of the water tariff in Spain, which consists of a fixed part and a variable part that depends on consumption and the composition of the household is not considered. Thus, as the number of household members grows, the household moves faster through the tariff sections, increasing the marginal price, although the fixed part is also divided among more people. Therefore, the positive coefficient of the number of household members shows a penalty for more populated households, as reveals the greater relative importance of the variable part of the tariff, which has a stronger impact on these households. Finally, the size of the municipality shows that, as the population increases, the price per person decreases possibly due to the presence of economies of scale. With regard to the regional variables, the region of residence and the occupied capacity of the reservoir are included as explanatory variables in Table 2 . In this line, large differences between regions with higher prices for households in more resource-scarce areas can be observed. These differences are smaller among the other areas, both in terms of price and scarcity, although it should be noted that these differences are present even when taking into account key aspects such as consumption, income and price. In other words, these regional differences are related to the disparity in characteristics shown by regions, for example, in terms of resource availability, as shown in Table A6, household composition or economic activities carried out. In any case, the increase in the Adjusted $\mathrm{R}^{2}$ reveals the explanatory importance of the regional variables. Finally, there is no clear evidence in the results related to the reservoirs due, in part, to the scarce information available in this aspect. Thus, precise information about the water supply is required in order to develop a better analysis of this aspect, so that the determinants of the tariff in the different regions of Spain can be studied.

\section{Discussion}

The results obtained provide valuable information about water consumption and price for the Spanish case. Regarding the consumption, the results allow to clarify the current situation of water consumption and pricing patterns in Spain. However, the inclusion of variables by region in the price models reveals a divergence between the different regions of the country, which indicates that the price of supply varies according to the place of residence. In addition, the estimated models included several relevant factors that allow to exclude them from the regional differences, although a significant number of aspects linked to the socioeconomic conditions or to the situation of the water supply could not be assessed. 
In order to improve management, the elasticity obtained in this investigation has shown a relatively strong price reaction on Spanish users, so that a price increase would have a significant impact. This effect is observed in advanced countries [7,23,28], but in emerging and developing countries is reduced [29,30]. Specifically, for the case of the United States the range of elasticities is between -0.02 and -3.33 , although $90 \%$ of the cases show an elasticity between 0 and -0.75 [8]. As for the emerging countries, a meta-analysis developed with different estimates from Iran found elasticities between -0.428 and -0.312 [37] while, for emerging and developing countries as a whole, the range of elasticities extends from -0.3 to -0.6 [36]. These are countries which, despite having limited monetary resources, have a low reaction to price due to the need for water resources from their population. This aspect is essential in the pursuit of adequate cost financing and efficient management of water resources. Thus, the results obtained show how the variation in the price would reduce consumption, but it would be necessary to specify the effect on household budgets and on the financing of water services. In terms of consumption, new measures affecting consumption are necessary due to the $60.29 \%$ of Spanish households exceeding the consumption recommended by the World Health Organization according to the employed data. However, it should be noted that further study is needed on whether or not a certain consumption threshold is exceeded. In this case, showing lower consumption than recommended may be related not only to consumption efficiency, but also to lack of access to the water needed to adequately supply all needs, among other reasons. Greece is a good example of the ineffectiveness of prices as an individual measure to influence consumption, since in this country price measures did not reduce consumption and regulatory and user awareness measures were needed to induce efficiency [38]. Although the results in Spain suggest that consumption would decrease, consider that price measures alone would not be efficient, and a policy mix should be applied is reasonable [39]. In this sense, awareness measures would make it possible to transmit the situation of scarcity suffered in a significant part of the country, while regulation establishes the conditions under which the supply service must be provided, thus making it possible to encourage the installation of water-saving technologies. In addition, the measures must be acceptable to the public [40].

Therefore, while price measures are reasonable due to the lack of cost recovery, they must be carefully designed. The results obtained have demonstrate several characteristics that should be assessed when introducing prices modifications. In this respect, income is a relevant factor as it not only influences consumption, but also conditions the reaction to price by users. In addition, the household structure is a key and complex aspect, since there are different household compositions with their own socioeconomic characteristics distributed across different regions. For this reason, the current water tariff structure is not appropriate as it does not adequately tax the different types of water service users that exist. However, the municipalities do not have the appropriate information to include these aspects in the water tariff, so that both their analysis and inclusion would require significant institutional work. This public research would allow to address the financing and pricing problem of water services more precisely, which would contribute not only to improving rates, but also to the development of complementary measures. Finally, due to the relatively high elasticity obtained ( 0.814 when it is usually less than 0.75$)$, the reaction to a tariff increase would be strong and the increase in income reduced, but both consumption and the cost of the service would decrease, so the best alternative would have to be analyzed in order to recover the costs.

As for the territorial aspect, implementing tariff modifications makes sense due to the lack of cost recovery of the Spanish hydrographic confederations [18,41]. In this respect, the level of cost recovery may vary between confederations, although in no case total costs are recovered, so that not only local actions, but also national measures are needed aiming at full cost recovery. Nevertheless, the local determination of the price of water services, as well as the unequal distribution of resources, generates disparity between regions and must be taken into account in the development of national policies. On the other hand, when the costs are not recovered, funds are received from the national government through the Ministry of ecological transition and the ministry of territorial policy and public functions (through regional 
institutions), as well as from European Regional Development Fund (ERDF). This implies the disparate arrival of external funds depending on the differences in cost recovery between confederations, funds not directly linked to the consumers who will enjoy the service. Of course, this does not mean that each region must pay individually for its own services because, in those regions where the situation is more complex and costly, the situation of households and public administrations would worsen. However, considering the situation of shortages in certain places, the lack of cost recovery and the need for external funds, management should be improved as much as possible. The lack of cost recovery needs to be studied in depth, as supplementing financing by external funds can be considered unfair. The water framework directive was implemented in a European context where, in general, the operation and maintenance costs of water services were recovered, so no major impact on price was expected where this recovery was achieved [42]. Unfortunately, in the case of Spain, costs were not recovered and, despite this and the new regulations, prices have not evolved in such a way as to complete the recovery of financial costs $[18,41]$. Thus, since the WFD pursue the adequate costs financing, these transfers should be reduced as much as possible, but any tariff changes that aim for this should be carefully considered. In this respect, the Directive provides for the possibility of not completing cost recovery where doing so would have an excessive impact on users. On the other hand, there is a positive side to source-based transfers of funds. In other words, citizens with higher incomes contribute to a greater extent to finance the public sector, so they also contribute more to these external funds, with its slight redistributive effect.

In short, the river basin approach contradicts the revenue structure of water services, leading to inefficiencies and management problems, although it would not be appropriate to blame the approach for all problems. The WFD has been unable to reformulate water resources management in Europe, despite its ambitious goals [43]. In this sense, the regional differences and imbalances influence the user and must be valued in regulatory terms with the objective of inducing efficiency and equity. However, the situation is complex and requires a better understanding of the exact effect of the basin approach, of the regional determination of payments for water services and of the different types of applicable policies. Thus, a combination of measures could be designed to adequately address the various problems that Spain faces in terms of water resources management.

\section{Conclusions}

The main objective of this study was to analyze the reaction of consumers to the price of water, as well as the influence of other factors of interest in terms of consumption, which was pursued through regression techniques. These models allowed us to estimate the variation in income in the event of introducing a tax or tariff modification, in addition to being useful for analyzing the determinants of price.

The econometric techniques used provide relevant information about the impact of certain variables, showing a relatively high sensitivity of Spanish consumers to price variations. Therefore, a price increase without changing the structure of the tariff would not increase revenues in the desired way due to the relatively strong reduction in consumption. Furthermore, the estimations allow us to observe how other aspects affect price and consumption, as well as that the tariffs are penalizing households with more members despite being designed to progressively pricing consumption. Thus, modifying the water tariff structure, as well as to accompany it with regulatory measures, would be appropriate in order to improve the financing of water services. The territorial variables introduced show significant differences between regions even after controlling for several aspects, highlighting the relatively high prices paid by regions with large shortages. The analysis provides new information linked to regional differences and their relation to the WFD. This occurs in a situation of lack of cost recovery from the Spanish hydrographic confederations, which implies arrivals of external funds in order to complete the financing. For this reason, the structure of water revenues must be changed in order to avoid transfers that could be considered unfair 
and to move towards sustainability of water resources. In this respect, finding a balance between economic, regulatory and awareness measures is essential.

Lastly, several limitations affect this investigation. First, the data employed does not allow to include tourism or seasonal aspects in the analysis. In addition, linking these data to cost recovery is complicated due to the different regional scales of the data and the river basin approach. Consequently, further and more accurate research on the water price situation of households would be valuable. In this sense, correctly addressing the simultaneity bias and obtaining more information about households, cities and water supply would be very useful, establishing the possibility of carrying out more analysis on the price of water in Spanish regions. In particular, regions that are close to each other may show relationships between variables derived from proximity, so having information about the location of observations would be very useful.

In summary, improving the management of the resource by introducing efficiency-inducing modifications is of great interest, for example by carrying out an awareness campaign or by modifying the regulation or the tariff structure. In particular, since there is a relatively high consumption of water by Spanish households, measures of awareness or regulation would be reasonable, as the stimulus for the installation of water-saving technologies. This type of measure does not exist at present, but the main measure is the water tariff. However, this has proved to be incapable of inducing efficiency in consumption, of adequately financing water services and of affecting the different households in an equitable manner. Altering the balance between the fixed and variable parts of the invoice or including the structure of the household in the tariff would improve accuracy in obtaining income, as well as improving cost recovery if accompanied by an increase in the average price. However, it should be noted that households show significant differences in income, so these changes should affect households without unduly affecting their budgets, that is, tariffs should be affordable.

Author Contributions: M.G.-L. is the main author of the text with the supervision of B.M. In addition, B.M. has contributed in the elaboration of the econometric estimates and in the collection and preparation of the data. All authors have read and agreed to the published version of the manuscript.

Acknowledgments: This work was supported by the Office of the Vice President of Research and Knowledge Transfer of the University of Alicante, Spain (Marcos García-López has a scholarship for The Training of University Teachers from the University of Alicante, FPU-UA-2018), by the Water Chair of the University of Alicante-Alicante Provincial Council (2020), by the University Institute of Water and Environmental Sciences of the University of Alicante and by the Hábitat5U network of excellence. Furthermore, we thank the Guest Editor Joaquin Melgarejo and the reviewers and editors whose comments have contributed to the improvement of this research.

Conflicts of Interest: The authors declare no conflict of interest.

Data Availability Statement: The data utilized (Household budget survey) is available on the Spanish National Statistics Institute website, which can be accessed through https://www.ine.es/dyngs/INEbase/ en/operacion.htm?c=Estadistica_C\&cid=1254736176806\&menu=resultados\&secc $=1254736195147 \&$ idp=

1254735976608\#!tabs-1254736194790. As already mentioned during the article, the 2016, 2017 and 2018 edition are used. In addition, it should be noted that the previous webpage can be consulted in English, but the design of the survey is only available in Spanish. Finally, the data about Water exploitation index plus by river basin is available at the webpage of the European Environment Agency through https://www.eea.europa.eu/data-and-maps/explore-interactive-maps/water-exploitation-index-for-river-2. 


\section{Appendix A}

Table A1. Water exploitation index plus by river basin for the four seasons of 2015 (\%).

\begin{tabular}{ccccc}
\hline River Basin & January $\mathbf{1}$ & April 1 & July 1 & October 1 \\
\hline Galician Coast & 1.73 & 5.33 & 7.15 & 2.95 \\
Minho and Lima & 1.62 & 4.77 & 6.18 & 3.67 \\
Douro & 2.63 & 33.53 & 56.05 & 5.82 \\
Basque County internal basins & 5.12 & 11.81 & 24.97 & 14.03 \\
Ebro & 27.75 & 45.78 & 47.08 & 5.76 \\
Internal Basins of Catalonia & 20.08 & 49.01 & 71.64 & 26.41 \\
Tagus and Western Basins & 13.52 & 49.78 & 78.86 & 14.86 \\
Jucar & 73.25 & 101.06 & 123.46 & 15.87 \\
Segura & 249.31 & 296.67 & 258.72 & 11.47 \\
Guadiana & 49.95 & 103.89 & 131.39 & 8.97 \\
Andalusia Atlantic Basins & 6.31 & 16.89 & 15.8 & 8.76 \\
Andalusia Mediterranean & 10.43 & 25.74 & 33.91 & 19.7 \\
Basins & 13.58 & 33.87 & 68.81 & 36.45 \\
Balearic Islands & & &
\end{tabular}

Source: own elaboration from European Environment Agency data.

Table A2. Descriptive statistics of exploratory variables.

\begin{tabular}{|c|c|c|}
\hline Variable & Mean & Std Dev \\
\hline Water consumption per household $\left(\mathrm{m}^{3}\right)$ & 130.46 & 107.09 \\
\hline Unit price of water consumed $\left(€ / \mathrm{m}^{3}\right)$ & 1.36 & 0.48 \\
\hline Annual income of the household $(€)$ & $25,312.46$ & $16,543.57$ \\
\hline Number of members in the household & 2.64 & 1.23 \\
\hline Weight of water invoice on income (\%) & 0.88 & 0.91 \\
\hline Andalusia & 0.11 & 0.31 \\
\hline Aragon & 0.04 & 0.20 \\
\hline Asturias & 0.04 & 0.19 \\
\hline Balearic Islands & 0.03 & 0.18 \\
\hline Canary Islands & 0.05 & 0.21 \\
\hline Cantabria & 0.04 & 0.18 \\
\hline Castilla and León & 0.07 & 0.25 \\
\hline Castilla-La Mancha & 0.05 & 0.23 \\
\hline Catalonia & 0.09 & 0.29 \\
\hline Valencia & 0.08 & 0.27 \\
\hline Extremadura & 0.04 & 0.21 \\
\hline Galicia & 0.05 & 0.23 \\
\hline Madrid & 0.08 & 0.26 \\
\hline Murcia & 0.04 & 0.21 \\
\hline Navarra & 0.03 & 0.18 \\
\hline Basque Country & 0.10 & 0.31 \\
\hline La Rioja & 0.03 & 0.18 \\
\hline Ceuta & 0.01 & 0.07 \\
\hline Melilla & 0.01 & 0.07 \\
\hline Residing in an area where reservoirs have an occupied capacity of less than $40 \%$ & 0.05 & 0.22 \\
\hline Residing in an area where reservoirs have an occupied capacity between $40 \%$ and $55 \%$ & 0.15 & 0.35 \\
\hline Residing in an area where reservoirs have an occupied capacity between $55 \%$ and $70 \%$ & 0.36 & 0.48 \\
\hline Residing in an area where reservoirs have an occupied capacity of more than $70 \%$ & 0.44 & 0.50 \\
\hline Residing in a city with less than 10,000 inhabitants & 0.38 & 0.49 \\
\hline Residing in a city between 10,000 and 20,000 inhabitants & 0.13 & 0.33 \\
\hline Residing in a city between 20,000 and 50,000 inhabitants & 0.16 & 0.36 \\
\hline Residing in a city between 50,000 and 100,000 inhabitants & 0.11 & 0.31 \\
\hline Residing in a city with more than 100,000 inhabitants & 0.23 & 0.42 \\
\hline Residing in a low-density area & 0.28 & 0.45 \\
\hline Residing in a medium density area & 0.25 & 0.43 \\
\hline Residing in a high-density area & 0.48 & 0.5 \\
\hline Observation of the year 2016 & 0.34 & 0.47 \\
\hline Observation of the year 2017 & 0.34 & 0.47 \\
\hline Observation of the year 2018 & 0.33 & 0.47 \\
\hline
\end{tabular}

Source: own elaboration from INE data. 
Table A3. Results of the variance inflation factor (VIF) in the consumption model.

\begin{tabular}{ccc}
\hline Variable & VIF & 1/VIF \\
\hline Unit price*monthly income & 9.57 & 0.105 \\
Monthly income of the household & 7.88 & 0.127 \\
High population density & 7.26 & 0.138 \\
Town of more than 100,000 & 5.42 & 0.185 \\
Town of between 20,000 and 50,000 inhabitants & 3.75 & 0.267 \\
Town of between 50,000 and 100,000 inhabitants & 3.1 & 0.323 \\
Unit price & 2.62 & 0.381 \\
Average population density & 2.13 & 0.469 \\
Year 2018 & 1.52 & 0.660 \\
Year 2017 & 1.34 & 0.745 \\
Mean VIF & 1.34 & 0.746 \\
Number of members in the household & 1.15 & 0.870 \\
\hline
\end{tabular}

Source: own elaboration from INE data.

Table A4. Results of the variance inflation factor (VIF) in the price model (with regions).

\begin{tabular}{|c|c|c|}
\hline Variable & VIF & 1/VIF \\
\hline High population density & 8.16 & 0.123 \\
\hline Andalusia & 6.02 & 0.166 \\
\hline Town of more than 100,000 & 5.97 & 0.167 \\
\hline Catalonia & 5.83 & 0.172 \\
\hline Madrid & 5.26 & 0.190 \\
\hline Consumption*Income & 4.91 & 0.204 \\
\hline Valencia & 4.46 & 0.224 \\
\hline Town of between 20,000 and 50,000 inhabitants & 4 & 0.250 \\
\hline Town of between 50,000 and 100,000 inhabitants & 3.34 & 0.300 \\
\hline Consumption per household & 3.2 & 0.313 \\
\hline Castilla and León & 2.79 & 0.359 \\
\hline Galicia & 2.73 & 0.366 \\
\hline Basque Country & 2.71 & 0.370 \\
\hline Monthly income of the household & 2.64 & 0.379 \\
\hline Canary Islands & 2.53 & 0.395 \\
\hline Castilla-La Mancha & 2.45 & 0.409 \\
\hline Average population density & 2.35 & 0.426 \\
\hline Murcia & 2.02 & 0.494 \\
\hline Balearic Islands & 1.85 & 0.540 \\
\hline Asturias & 1.81 & 0.551 \\
\hline Extremadura & 1.8 & 0.555 \\
\hline Town of between 10,000 and 20,000 inhabitants & 1.62 & 0.618 \\
\hline Navarra & 1.48 & 0.674 \\
\hline Cantabria & 1.46 & 0.687 \\
\hline Year 2018 & 1.34 & 0.745 \\
\hline Year 2017 & 1.34 & 0.747 \\
\hline La Rioja & 1.24 & 0.805 \\
\hline Number of members in the household & 1.19 & 0.838 \\
\hline Ceuta & 1.07 & 0.934 \\
\hline Melilla & 1.07 & 0.937 \\
\hline Mean VIF & 2.95 & \\
\hline
\end{tabular}

Source: own elaboration from INE data. 
Table A5. Averages of the main variables of the analysis by region and for the total of Spain.

\begin{tabular}{|c|c|c|c|c|c|c|}
\hline & $\begin{array}{l}\text { Number of Members } \\
\text { in the Household }\end{array}$ & $\begin{array}{l}\text { Monthly Income of } \\
\text { the Household }(f)\end{array}$ & Unit Price $(€)$ & $\begin{array}{l}\text { Consumption per } \\
\text { Household }\left(\mathrm{m}^{3}\right)\end{array}$ & $\begin{array}{l}\text { Total Price per } \\
\text { Household }(\epsilon)\end{array}$ & $\begin{array}{c}\text { Weight of Water } \\
\text { Invoice on Income (\%) }\end{array}$ \\
\hline Andalusia & 2.61 & 1800.02 & 1.39 & 136.09 & 168.79 & 1.09 \\
\hline Aragon & 2.42 & 2104.69 & 1.17 & 78.99 & 83.64 & 0.45 \\
\hline Asturias & 2.24 & 2061.55 & 1.28 & 129.87 & 134.55 & 0.75 \\
\hline Balearic Islands & 2.57 & 2224.08 & 1.43 & 203.93 & 256.15 & 1.28 \\
\hline Canary Islands & 2.61 & 1721.55 & 1.46 & 154.65 & 204.21 & 1.42 \\
\hline Cantabria & 2.40 & 2035.51 & 1.23 & 113.21 & 128.76 & 0.74 \\
\hline Castilla and León & 2.35 & 1991.32 & 1.16 & 107.39 & 102.37 & 0.57 \\
\hline Castilla-La Mancha & 2.58 & 1750.83 & 1.24 & 109.94 & 121.93 & 0.76 \\
\hline Catalonia & 2.47 & 2176.07 & 1.67 & 137.04 & 192.67 & 0.98 \\
\hline Valencia & 2.48 & 1958.80 & 1.61 & 123.57 & 179.73 & 1.07 \\
\hline Extremadura & 2.49 & 1612.37 & 1.31 & 101.01 & 123.84 & 0.82 \\
\hline Galicia & 2.47 & 1890.10 & 1.22 & 112.96 & 125.58 & 0.77 \\
\hline Madrid & 2.49 & 2402.18 & 1.62 & 157.38 & 221.96 & 1.07 \\
\hline Murcia & 2.73 & 1949.14 & 1.43 & 164.45 & 214.69 & 1.30 \\
\hline Navarra & 2.47 & 2128.95 & 1.31 & 113.64 & 135.05 & 0.69 \\
\hline Basque Country & 2.38 & 2472.32 & 1.16 & 111.42 & 120.72 & 0.54 \\
\hline La Rioja & 2.40 & 2022.15 & 1.16 & 122.04 & 122.09 & 0.68 \\
\hline Ceuta & 3.15 & 2218.73 & 1.33 & 151.79 & 195.92 & 1.27 \\
\hline Melilla & 3.18 & 2192.67 & 0.67 & 215.76 & 120.02 & 0.78 \\
\hline Spain & 2.64 & 2109.37 & 1.36 & 130.46 & 160.00 & 1.09 \\
\hline
\end{tabular}

Source: own elaboration from INE data.

Table A6. Occupied capacity of reservoirs by region except the insular territories, Ceuta and Melilla.

\begin{tabular}{ccc}
\hline & Occupied Capacity at Present (\%) & Occupied Capacity 10 years Average (\%) \\
\hline Andalusia & 46.96 & 66.50 \\
Aragon & 79.24 & 67.94 \\
Asturias & 80.37 & 79.55 \\
Cantabria & 73.91 & 71.30 \\
Castilla and León & 71.27 & 66.93 \\
Castilla-La Mancha & 32.97 & 43.13 \\
Catalonia & 79.13 & 74.87 \\
Valencia & 41.1 & 49.34 \\
Extremadura & 48.82 & 69.63 \\
Galicia & 85.87 & 71.43 \\
Madrid & 59.72 & 74.53 \\
Murcia & 41.22 & 30.41 \\
Navarra & 79.39 & 59.17 \\
Basque Country & 75.4 & 75.40 \\
La Rioja & 69.12 & 58.82 \\
\hline
\end{tabular}

Source: own elaboration with data from embalses.net.

\section{References}

1. Prats, D. La reutilización de aguas depuradas regeneradas a escala mundial: Análisis y prospectivas. Agua Territ. 2016, 8, 10-21. [CrossRef]

2. Navarro, T. Water reuse and desalination in Spain-challenges and opportunities. J. Water Reuse Desalin. 2018, 8, 153-168. [CrossRef]

3. Renzetti, S. Evaluating the welfare effects of reforming municipal water prices. J. Environ. Econ. Manag. 1992, 22, 147-163. [CrossRef]

4. Mansur, E.T.; Olmstead, S.M. The value of scarce water: Measuring the inefficiency of municipal regulations. J. Urban Econ. 2012, 71, 332-346. [CrossRef]

5. Carver, P.H.; Boland, J.J. Short-and long-run effects of price on municipal water use. Water Resour. Res. 1980, 16, 609-616. [CrossRef] 
6. Pinto, F.S.; Simões, P.; Marques, R.C. Water services performance: Do operational environment and quality factors count? Urban Water J. 2017, 14, 773-781. [CrossRef]

7. Young, R.A. Price elasticity of demand for municipal water: A case study of Tucson, Arizona. Water Resour. Res. 1973, 9, 1068-1072. [CrossRef]

8. Espey, M.; Espey, J.; Shaw, W.D. Price elasticity of residential demand for water: A meta-analysis. Water Resour. Res. 1997, 33, 1369-1374. [CrossRef]

9. World Health Organization. Domestic Water Quantity, Service Level and Health 2003. Available online: https://apps.who.int/iris/handle/10665/67884 (accessed on 4 June 2020).

10. Melgarejo, J.; López, M.I. La economía del ciclo urbano del agua en España. In Desafíos del Derecho de Aguas; Aranzadi: Pamplona, Spain, 2016.

11. Rogers, P.; De Silva, R.; Bhatia, R. Water is an economic good: How to use prices to promote equity, efficiency, and sustainability. Water Policy 2002, 4, 1-17. [CrossRef]

12. Pinto, F.S.; Marques, R.C. New era/new solutions: The role of alternative tariff structures in water supply projects. Water Res. 2017, 126, 216-231. [CrossRef]

13. Arbúes, F.; Barberán, R.; Villanúa, I. Price impact on urban residential water demand: A dynamic panel data approach. Water Resour. Res. 2004, 40. [CrossRef]

14. Hung, M.F.; Chie, B.T. Residential water use: Efficiency, affordability, and price elasticity. Water Resour. Manag. 2013, 27, 275-291. [CrossRef]

15. Hughes, N.; Hafi, A.; Goesch, T. Urban water management: Optimal price and investment policy under climate variability. Aust. J. Agric. Resour. Econ. 2009, 53, 175-192. [CrossRef]

16. Vatn, A. An institutional analysis of payments for environmental services. Ecol. Econ. 2010, 69, 1245-1252. [CrossRef]

17. European Union. Directive 2000/60/EC of the European Parliament and of the Council Establishing a Framework for the Community Action in the Field of Water Policy 2000. Available online: https://eur-lex.europa.eu/legalcontent/EN/ALL/?uri=celex:32000L0060 (accessed on 4 June 2020).

18. García-López, M.; Montano, B.; Melgarejo, J. Financing of water policy: Cost recovery of the hydrographic confederations of Spain. WIT Trans. Ecol. Environ. 2019, 234, 113-121. [CrossRef]

19. Tardieu, H.; Préfol, B. Full cost or "sustainability cost" pricing in irrigated agriculture. Charging for water can be effective, but is it sufficient? Irrig. Drain. J. Int. Comm. Irrig. Drain. 2002, 51, 97-107. [CrossRef]

20. Ray, I. 'Get the Price Right': Water Prices and Irrigation Efficiency. Econ. Political Wkly. 2005, 3659-3668. [CrossRef]

21. Melgarejo, J.; Prats, D.; Molina, A.; Trapote, A. A case study of urban wastewater reclamation in Spain: Comparison of water quality produced by using alternative processes and related costs. J. Water Reuse Desalin. 2016, 6, 72-81. [CrossRef]

22. Opaluch, J.J. A Test of Consumer Demand Response to Water Prices: Reply. Land Econ. 1984, 60. [CrossRef]

23. Billings, R.B.; Agthe, D.E. Price elasticities for water: A case of increasing block rates. Land Econ. 1980, 56, 73-84. [CrossRef]

24. Shin, J.S. Perception of price when price information is costly: Evidence from residential electricity demand. Rev. Econ. Stat. 1985, 591-598. [CrossRef]

25. Howe, C.W.; Linaweaver, F.P., Jr. The impact of price on residential water demand and its relation to system design and price structure. Water Resour. Res. 1967, 3, 13-32. [CrossRef]

26. Ipe, V.C.; Bhagwat, S.B. Chicago's water market: Dynamics of demand, prices and scarcity rents. Appl. Econ. 2002, 34, 2157-2163. [CrossRef]

27. Ruijs, A.; Zimmermann, A.; van den Berg, M. Demand and distributional effects of water pricing policies. Ecol. Econ. 2008, 66, 506-516. [CrossRef]

28. Gaudin, S.; Griffin, R.C.; Sickles, R.C. Demand specification for municipal water management: Evaluation of the Stone-Geary form. Land Econ. 2001, 77, 399-422. [CrossRef]

29. Martínez-Espiñeira, R.; Nauges, C. Is all domestic water consumption sensitive to price control? Appl. Econ. 2004, 36, 1697-1703. [CrossRef] 
30. Grafton, R.Q.; Ward, M.B. Prices versus rationing: Marshallian surplus and mandatory water restrictions. Econ. Rec. 2008, 84, S57-S65. [CrossRef]

31. Jordan, J.L. Externalities, water prices, and water Transfers. J. Am. Water Resour. Assoc. 1999, 35, 1007-1013. [CrossRef]

32. Barrett, G. Water conservation: The role of price and regulation in residential water consumption. Econ. Pap. J. Appl. Econ. Policy 2004, 23, 271-285. [CrossRef]

33. Martinez-Espineira, R. Price specification issues under block tariffs: A Spanish case study. Water Policy 2003, 5, 237-256. [CrossRef]

34. Martínez-Espiñeira, R.; García-Valiñas, M.A.; González-Gómez, F. Is the pricing of urban water services justifiably perceived as unequal among Spanish cities? Int. J. Water Resour. Dev. 2012, 28, 107-121. [CrossRef]

35. Yoo, J.; Simonit, S.; Kinzig, A.P.; Perrings, C. Estimating the price elasticity of residential water demand: The case of Phoenix, Arizona. Appl. Econ. Perspect. Policy 2014, 36, 333-350. [CrossRef]

36. Nauges, C.; Whittington, D. Estimation of water demand in developing countries: An overview. World Bank Res. Obs. 2010, 25, 263-294. [CrossRef]

37. Abolhasani, L.; Tajabadi, M.; Shahnoushi Forushahi, N. Price elasticity of residential water demand: A Meta analysis of studies on water demand, (case study: Iran). In Proceedings of the 30th International Conference of Agricultural Economists, Vancouver, BC, Canada, 28 July-2 August 2018. [CrossRef]

38. Zikos, D. Urban water dilemmas under the multi-dimensional prism of sustainability. Trans. Bus. Econ. 2008, 8, 413-422.

39. Villamayor-Tomas, S.; Thiel, A.; Amblard, L.; Zikos, D.; Blanco, E. Diagnosing the role of the state for local collective action: Types of action situations and policy instruments. Environ. Sci. Policy 2019, 97, 44-57. [CrossRef]

40. Alcon, F.; Martin-Ortega, J.; Berbel, J.; De Miguel, M.D. Environmental benefits of reclaimed water: An economic assessment in the context of the Water Framework Directive. Water Policy 2012, 14, 148-159. [CrossRef]

41. PWC. La gestión del agua en España, análisis de la situación actual del sector y retos futuros. PriceWaterhouseCoopers 2014. Available online: https://www.pwc.es/es/publicaciones/energia/gestion-aguaespana-analisis-retos.html (accessed on 4 June 2020).

42. Kallis, G.; Butler, D. The EU water framework directive: Measures and implications. Water policy 2001, 3, 125-142. [CrossRef]

43. Zikos, D.; Hagedorn, K. Competition for water resources from the European perspective. In Competition for Water Resources; Elsevier: Amsterdam, The Netherlands, 2017; pp. 19-35. [CrossRef]

(C) 2020 by the authors. Licensee MDPI, Basel, Switzerland. This article is an open access article distributed under the terms and conditions of the Creative Commons Attribution (CC BY) license (http://creativecommons.org/licenses/by/4.0/). 